Article

\title{
An Evaluation of the Delivery of Medicines Using Drones
}

\author{
Michelle Sing Yee Hii ${ }^{1}$, Patrick Courtney ${ }^{2}$ and Paul G. Royall ${ }^{1, *(1)}$ \\ 1 Institute of Pharmaceutical Science, Department of Pharmacy, Faculty of Life Sciences \& Medicine, \\ King's College London, 150 Stamford Street, London SE1 9NH, UK \\ 2 tec-connection, Oberlohnstr 3, D78467 Konstanz, Germany \\ * Correspondence: paul.royall@kcl.ac.uk
}

Received: 29 April 2019; Accepted: 22 June 2019; Published: 27 June 2019

check for updates

\begin{abstract}
This study tests the impact of drone transportation on the quality of a medicine. Modelling the critical process parameters of drone flight, the effects of temperature and vibration on insulin were investigated using the pharmacopoeia methods. The medicine, Actrapid, ( $3.5 \mathrm{mg} / \mathrm{mL}$ of insulin), was flown by a quad-rotor drone. Insulin stored between -20 and $40{ }^{\circ} \mathrm{C}$ for $30 \mathrm{mins}$, and subjected to vibration $\left(0-40 \mathrm{~Hz}, 25^{\circ} \mathrm{C}, 30 \mathrm{mins}\right)$ passed the pharmacopeia tests. Dynamic light scattering identified the active tetrameric and hexameric forms of insulin post testing. Vibration frequencies during drone flight were between 0.1 and $3.4 \mathrm{~Hz}$. There was no evidence of visible insulin aggregates following the drone transportation. The differences in UV absorbance readings between flown Actrapid and controls were insignificant $(p=0.89)$. No adverse impact of drone transport on insulin was observed. This study provides supporting evidence that drone transportation of medicinal products containing insulin is feasible. The authors recommend that when considering the drone delivery of medicines five tests need to be applied. These tests must determine the safe flight time and range, the quality of the medicine post flight, the onboard conditions experienced by the medicine, the security of the drone supply chain and the effect of drone failure on both the medicine and the environment.
\end{abstract}

Keywords: medicine delivery; insulin; quality of medicines; medicine stability; drone delivery; healthcare logistics; quality by design

\section{Introduction}

Unmanned aircraft systems were historically used exclusively by the military [1]. Currently, the use of remotely piloted aircraft systems (RPAS) and small drones has expanded to perform civilian tasks [1,2] such as, supporting search and rescue operations [2-4], monitoring weather and traffic flows [5], delivering goods [4,6], and of course as a platform for aerial photography. Drones are being employed to effect change in the environment; a good example is in agriculture, where efficiencies may be made by employing drones to spray fields and track crop growth patterns [6].

However, one of the most exciting areas of drone development is within the healthcare industries. Such applications include delivering medicines, vaccines [7], blood [8] and other medical supplies $[9,10]$ that are urgently needed in inaccessible areas. Supply challenges are frequently caused by poor transport networks, extreme weather conditions, natural disasters or traffic congestion in urban areas [11]. Delivery by drone could be a solution to such problems. An illustrative example is the delivery of medical supplies from the Wise County Regional airport to the clinics in rural Virginia, where the total delivery time over 39 miles was substantially reduced from 90 minutes by road to less than 30 minutes by the use of drones [12]. United Parcel Service and Zipline have been working on a drone network to allow 50-150 daily deliveries of blood and vaccines to 20 clinics in remote areas of Rwanda, Africa [4]. The Californian drone company, Matternet, has delivered medications to camps in 
Haiti following earthquakes [6] and to remote areas in the Dominican Republic, Lesotho, Bhutan [2], Papua New Guinea and Switzerland using automated drones with capacities of up to $2 \mathrm{~kg}$, which were flown over $10 \mathrm{~km}$ within 18 minutes [12]. Following the testing in Lesotho, Matternet estimated that it would cost $\$ 900,000$ to operate 50 base stations and 150 drones (24 cents/flight) throughout the capital city of Maseru, which could be more cost-effective than building roads (estimated cost to build a $2 \mathrm{~km}$ one-lane road = \$1 million) [2]. In Germany, three generations of parcelcopter operated by DHL Parcel have been tested respectively to deliver blood samples across the Rhine River at Bonn $(1 \mathrm{~km})$, deliver medications and other urgently needed materials to Juist (a North Sea island $12 \mathrm{~km}$ off the coast of Germany) [6], and deliver 130 parcels ( 2 kg each) of urgently needed medicines in January-March between automated Skyports in Reit im Winkl and Winklmoosalm (two Bavarian Alpine villages), which reduced the 30-minute journey time by road in winter to eight minutes [12].

In the healthcare context, the timely delivery of medications, vaccines and blood is crucial [12]. Drones can potentially overcome the logistic challenges as they are not subjected to traffic delays [13], and most importantly, they are able to reach regions that lack adequate roads faster. However, for delivery of fragile medications, blood [14] and diagnostic clinical laboratory specimens [15-17], drones are practical only if the quality of transported products is not adversely affected. Thus, drones as a novel method for medicine transportation, must be tested to determine their impact on medicine quality.

In the United Kingdom, drone delivery has a potential to thrive as reported in Nesta's Flying High report July 2018 [5]. The Flying High Challenge explored the use of drones in urban areas and the technical and economic feasibility of delivering blood samples or medical supplies between hospitals (Guy's and St Thomas') was evaluated [5]. A number of challenges were identified, in particular, the legislations requiring flying drones in the line-of-sight $[18,19]$. Apart from such regulatory and safety issues, drones exhibit some technical limitations [4] with regards to the battery life, payload capacity and maximum coverable distance [12]. Furthermore, the misuse of drones to deliver illegal drugs to prisons has led to low public confidence and acceptance of this technology $[12,20]$. Critically however, no information on the quality of medicines delivered using drones was considered in the report, which highlights a significant knowledge gap. While a few pilot studies have been carried out on the drone delivery of medicines to remote areas [4,6], there has been little consideration of the impact of the flight conditions on the quality of the drone-delivered medicines. Hence, the feasibility of delivering a medicine that is highly sensitive to environmental stresses is investigated in this study.

Current unmanned aircraft systems (UAS) or drones may be generally classified into fixed-wing or rotary-wing aircraft. Fixed-wing UAS are more efficient, have longer ranges and have greater payloads; however, rotary-wing drones take off and land vertically with the ability to hover during flight. For drone delivery of medicines in urban situations, rotor-based drones are more applicable, whereas rural locations benefit from the greater range associated with the fixed-wing aircraft. Udroiu and Blaj (2016) have made a compelling case for the design of vertical take off and landing (VTOL) drones that incorporate tilting wing technology and thus combine the benefits of both rotor- and fixed-wing aircraft. For all drone configurations the same critical process parameters associated with flight will impact on the stability of medicines transported by these systems.

Insulin was chosen as the model medication in this investigation as it is one of the most important life-saving drugs in treating type I diabetes [21]. Moreover, insulin is a sensitive peptide-based drug, which easily unfolds to cause irreversible aggregation when subjected to environmental stresses [22], such as high temperatures and exposure to vibration/agitation. Alteration of insulin's structure will impair its biological efficacy [22]. This study highlights the importance of maintaining insulin quality during drone transportation. Any compromise in medicine quality is likely to be detrimental to a patient's health and wellbeing.

The aim of our study is to examine the impact of drone transport on a form of human insulin used by diabetics. We selected the medicinal product, Actrapid and flew this product contained in its original packaging, glass vials held within a cardboard box, by a small, commercially available drone. 
Under a quality by design, QbD, framework, (International Council for Harmonisation, Q8 [23]), a set of critical quality attributes (CQA) is established to ensure quality, safety and efficacy of the medicine for the patient. Critical material attributes (CMA) represent a set of properties for an input material that should be within limits to ensure the desired quality of output material. In this study, we have selected the formation of irreversible aggregates as an indicator of insulin instability [24]. Analytical-grade insulin was used to develop and validate the stability-indicating tests applied in this study. A set of critical process parameters (CPP), whose variability has an impact on the CQA, should be monitored or controlled to ensure the process produces the desired quality. In this study, the primary critical process parameters of interest selected were temperature and vibration, along with air pressure and relative humidity ( $\mathrm{RH} \%)$, Table 1.

Table 1. Critical process parameters and critical material attributes for the drone-flown insulin.

\begin{tabular}{ccccc}
\hline & Test Scenario & Parameter & Conditions & Time Course \\
\cline { 2 - 5 } $\begin{array}{c}\text { CPP process } \\
\text { parameter }\end{array}$ & Lab stress test & Temperature & $-20 \ldots 100{ }^{\circ} \mathrm{C}$ & 24 hours, 30 minutes \\
\cline { 2 - 4 } & Lab stress test & Vibration & $3-40 \mathrm{~Hz}$ & 30 minutes \\
\cline { 2 - 4 } & Drone flight & Duration, pressure, RH\% & Ambient & $9 \pm 2$ minutes \\
\hline \multirow{2}{*}{$\begin{array}{c}\text { CMA material } \\
\text { attribute }\end{array}$} & Parameter & Measurement & British Pharmacopoeia (BP) Method [24] \\
\cline { 2 - 4 } & Aggregation & Clarity (turbidity) & Visual inspection, UV/Vis spectroscopy \\
\hline
\end{tabular}

To date, there is no published work on the impact of drone delivery on insulin quality. Obtaining this information will help to determine the feasibility of drone transportation of highly sensitive medicines.

\section{Materials and Methods}

The methods selected for this study were driven in the first instance by the pharmacopeia and quality by design frameworks which are used by medicines regulators and the pharmaceutical industry alike when testing the stability of a medicine [23,24]. After applying these methods to insulin flown by a drone, five key tests emerged from our study. The first three tests addressing flight time, medicine quality and onboard conditions were investigated by the methods outlined below. Whereas security of the supply chain and impact of drone failure will be addressed in a subsequent study.

\subsection{Stress Tests}

\subsubsection{Temperature}

Glass vials $(7 \mathrm{~mL})$ were filled with $0.2 \mathrm{~mL}$ human insulin solution $(10 \mathrm{mg} / \mathrm{mL}$, Sigma-Aldrich I9278) and stored for 24 hours. Storage temperatures were $-20{ }^{\circ} \mathrm{C}$ (freezer), $4{ }^{\circ} \mathrm{C}$ (control, fridge), $25^{\circ} \mathrm{C}$ (thermostatically controlled chamber, Memmert AtmoControl, relative humidity $60 \%$ ), $40{ }^{\circ} \mathrm{C}$ (thermostatically controlled chamber, Memmert AtmoControl, relative humidity $75 \%$ ) and $65^{\circ} \mathrm{C}$ (Genlab E3 drying cabinet, temperature measured by validated thermocouples) and $100{ }^{\circ} \mathrm{C}$ (Pickstone Ovens, temperature measured by thermometer). After 24 hours, samples were diluted to $0.2 \mathrm{mg} / \mathrm{mL}$ using ultra-pure water for analysis. Tests were repeated by using pharmaceutical equivalent concentration (10 $\mathrm{mL}$ of $3.5 \mathrm{mg} / \mathrm{mL}$, prepared by diluting the $10 \mathrm{mg} / \mathrm{mL}$ Sigma-Aldrich sample with ultra-pure water) and stored at $-20^{\circ} \mathrm{C}, 4{ }^{\circ} \mathrm{C}, 25^{\circ} \mathrm{C}$ and $40^{\circ} \mathrm{C}$ for 30 minutes.

\subsubsection{Vibration}

A vortex mixer was used to simulate the range of vibrations that a sample may experience during drone launch, flight and landing. Vibration produced at each agitation frequency of the vortex mixer 
(MS1 Minishaker, IKA) was measured using VibroChecker (ACE Stoßdämpfer GmbH) to establish a relationship between vibration and agitation frequency.

Glass vials $(7 \mathrm{~mL})$ were filled with insulin samples $(5 \mathrm{~mL}, 0.5 \mathrm{mg} / \mathrm{mL}$, diluted from $10 \mathrm{mg} / \mathrm{mL}$ with ultra-pure water) and mounted onto vortex mixer for agitation $\left(30\right.$ minutes at $\left.25^{\circ} \mathrm{C}\right)$. Agitation speeds with corresponding frequencies were $200 \mathrm{rpm}(3 \mathrm{~Hz}), 1400(23 \mathrm{~Hz})$ and $2400 \mathrm{rpm}(40 \mathrm{~Hz})$. A control $(0 \mathrm{~Hz})$ was prepared for comparison under the same ambient conditions [25]. After 30 minutes, samples were analysed. Tests were repeated with $10 \mathrm{~mL}$ of the pharmaceutical equivalent concentration of $3.5 \mathrm{mg} / \mathrm{mL}$ of insulin.

\subsection{Evaluation of the Degree of Opalescence by Visual Inspection and UV Spectrophotometry}

Using a black background and standard laboratory lighting [26], the opalescence of insulin samples was compared visually to the freshly prepared reference suspensions, (British Pharmacopoeia [24] and Supplementary Materials, S1). Turbidity was measured as absorbance at $350 \mathrm{~nm}$ using UV/Vis spectrophotometer (Perkin Elmer, Lambda 35) against ultra-pure water as blanks. Absorbance readings for reference suspensions I-IV and insulin samples after each stress test were recorded in triplicates and averaged. The results obtained from visual inspection were compared against the instrumental method (absorbance at $350 \mathrm{~nm}$ ).

\subsection{Particle Sizing Analysis by Dynamic Light Scattering (DLS)}

Aliquots of insulin were withdrawn from the vials after each stress test. Where indicated in the results, before analysis, samples were filtered by syringe filter (Fisherbrand, PES $0.45 \mu \mathrm{m}$ ) to avoid imprecise results due to huge scattering increments by large out of range particles, for example dust particles [26,27]. The measurements were performed in $2 \mathrm{~mL}$ semi-micro visible cuvettes at $25^{\circ} \mathrm{C}$ using Zetasizer Nano ZS (Malvern Instruments). Size distribution curves were obtained.

\subsection{Drone Tests}

A commercially available drone (DJI Mavic Air, $430 \mathrm{~g}, 168 \times 184 \times 64 \mathrm{~mm}$ when unfolded) [28] was used. It was powered by $2970 \mathrm{mAh}$ lithium polymer battery [28] and controlled using a remote controller connected to a smartphone application (DJI Go 4, iOS iPhone 7). The manufacture lists the air weight of the Mavic Air drone as $430 \mathrm{~g}$; however, no data were given concerning the maximum take off or payload weight. Thus, a set of experiments was untaken to determine the safe flight times as a function of load weight, the maximum load tested was just under $200 \mathrm{~g}$. These preliminary indoor and outdoor testing with trial payloads were used to define the test flight protocols used in the study with a flight time of $9 \pm 2$ minutes over a distance $0.81 \pm 0.18 \mathrm{~km}$. During testing, sport mode was avoided, and the drone was operated using its standard settings. The quad drone took off vertically to an altitude of 10 meters and then orbited a fixed point with a radius of $5 \mathrm{~m}$ and at a constant speed of $1.5 \mathrm{~m} / \mathrm{s}$.

\subsection{Drone Flight Involving Pharmaceutical Insulin}

Four insulin glass vials (Actrapid $3.5 \mathrm{mg} / \mathrm{mL}$, Novo Nordisk) were brought to the flight site (The Griffin Sportsground,). Glass vials in their original cardboard packaging ( $23.8 \mathrm{~g}$ each) were transported to the flight site in an insulated container within an hour. The vials were left in the cardboard packaging for flight testing. One vial acted as control, while the rest were flown for $9 \pm 2$ minutes covering a distance of $0.81 \pm 0.18 \mathrm{~km}$. A polypropylene-based sealing tape was used to fix the original box packaging of the vials of Actrapid to the top of the drone.

Flight protocols were followed, and the drone was controlled in the line-of-sight. The ambient temperature during the experimental window was -1 to $0{ }^{\circ} \mathrm{C}$. Other parameters include wind speed $2 \mathrm{mph}$, relative humidity $93 \%$ and air pressure 1021-1022 mbar [29]. After flight, the vials were transported back to the laboratory for analysis. In-flight vibration was measured using the same VibroChecker App as described in Section 2.1.2. In this experiment the iphone was fixed with a 
polypropylene-based sealing tape in the same position on top of the drone as used to carry the Actrapid samples. Vibration was measured in take off, flight and landing following the same mission as that used for the Actrapid samples.

\subsection{Statistical Analysis}

Statistical analysis was performed using excel 2010. A two-tailed unpaired t-test assuming equal variance was used to determine statistically significant differences. $p<0.05$ was considered significant.

\section{Results}

\subsection{Turbidity Standards (formazin)}

Formazin was used as the turbidity standard as recommended by the British Pharmocopeia [24]. A calibration curve was prepared to provide a robust assignment of the category of opalescence for subsequent visual experiments and validation [30,31] (Figure S1).

\subsection{Effects of Temperature on Insulin}

Insulin was kept at different storage temperatures for either 24 hours or 30 minutes. After 24 hours, all insulin samples (as received concentration of $10 \mathrm{mg} / \mathrm{mL}$ during storage, then diluted to $0.2 \mathrm{mg} / \mathrm{mL}$ for analysis) remained clear except those stored at $65^{\circ} \mathrm{C}$ and $100{ }^{\circ} \mathrm{C}$, where white flakes and long fibrils $(1$ to $5 \mathrm{~mm}$ ) were observed indicating irreversible aggregation leading to precipitation of insulin (Figure 1a). It should be noted that insulin $(3.5 \mathrm{mg} / \mathrm{mL})$ stored at $-20^{\circ} \mathrm{C}$ for 30 minutes was frozen (Figure $1 \mathrm{~b}$ ) and melting took $\sim 30$ minutes.

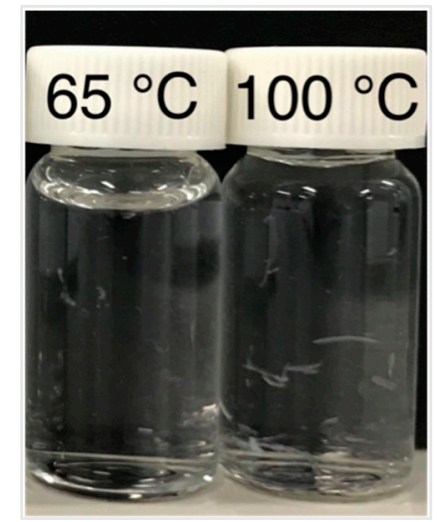

(a)

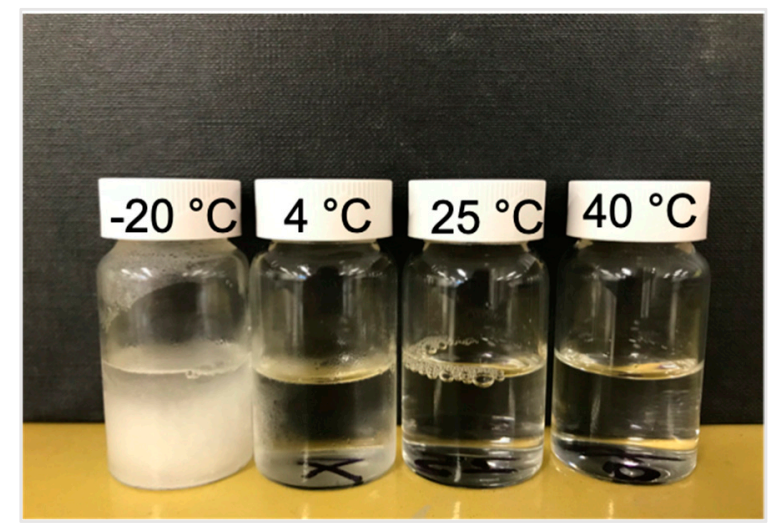

(b)

Figure 1. (a) Visual appearances after insulin $(0.2 \mathrm{~mL}$ of as received $10 \mathrm{mg} / \mathrm{mL})$ was stored at $65^{\circ} \mathrm{C}$ and $100{ }^{\circ} \mathrm{C}$ for 24 hours and diluted to $0.2 \mathrm{mg} / \mathrm{mL}$ for analysis. (b) Visual appearances after insulin $(10 \mathrm{~mL}$, $3.5 \mathrm{mg} / \mathrm{mL}$ ) was stored at $-20^{\circ} \mathrm{C}, 4{ }^{\circ} \mathrm{C}, 25^{\circ} \mathrm{C}$ and $40{ }^{\circ} \mathrm{C}$ for 30 minutes.

With UV spectrophotometry, the general trend showed a slight increase in absorbance at $350 \mathrm{~nm}$ with an increase in storage temperature (Figure 2). Beyond $40{ }^{\circ} \mathrm{C}$, steeper increase was observed (gradient was 10-folded). The differences in absorbance readings between all storage temperatures and $4{ }^{\circ} \mathrm{C}$ (control) were significant $(p<0.01)$, except $-20^{\circ} \mathrm{C}(p=0.71)$. Insulin stored at $-20{ }^{\circ} \mathrm{C}, 4{ }^{\circ} \mathrm{C}$, $25^{\circ} \mathrm{C}$ and $40^{\circ} \mathrm{C}$ passed the British Pharmacopoeia (BP) solution clarity test for injections, while insulin stored at $100^{\circ} \mathrm{C}$ failed. It should be noted that insulin stored at $65^{\circ} \mathrm{C}$ passed the test by absorbance but failed by visual inspection (Figure 2a). When $3.5 \mathrm{mg} / \mathrm{mL}$ insulin was stored at temperatures that mimic a 30-minute drone delivery $\left(-20^{\circ} \mathrm{C}, 4^{\circ} \mathrm{C}, 25^{\circ} \mathrm{C}\right.$ and $\left.40{ }^{\circ} \mathrm{C}\right)$, all samples passed the test. The differences in absorbance readings between $-20^{\circ} \mathrm{C}(p=0.55), 25^{\circ} \mathrm{C}(p=0.17)$ and $40{ }^{\circ} \mathrm{C}(p=0.05)$ with $4{ }^{\circ} \mathrm{C}$ (control) were insignificant. 
(a)

a) $10 \mathrm{mg} / \mathrm{mL}$, diluted to $0.2 \mathrm{mg} / \mathrm{mL}$ after storage

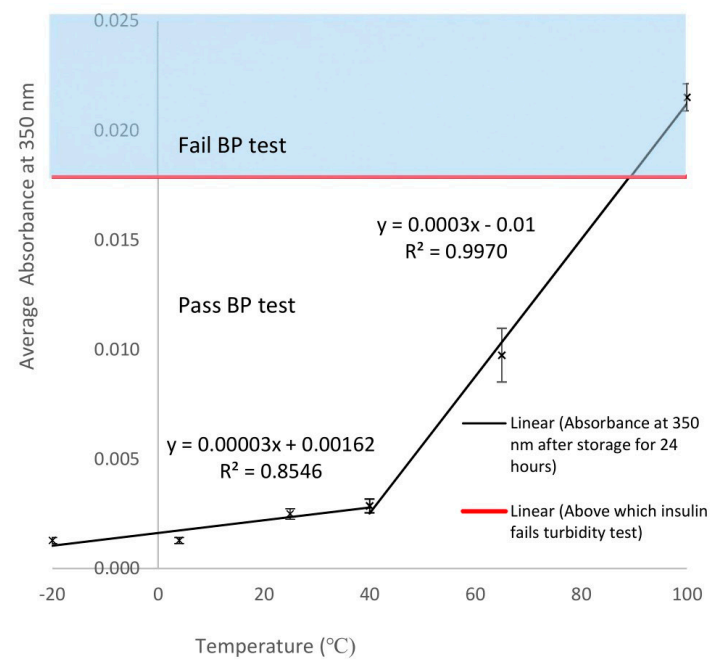

(b)

Pharmaceutical equivalent concentration

$(3.5 \mathrm{mg} / \mathrm{mL})$

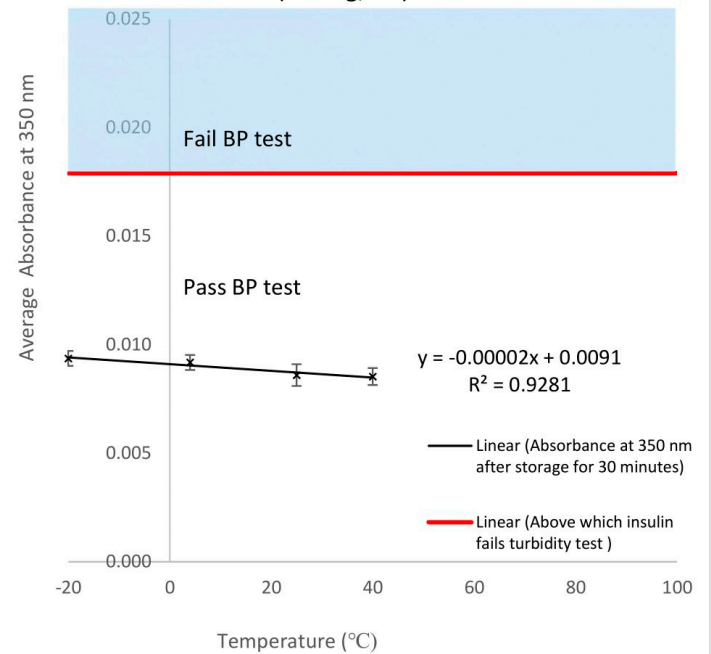

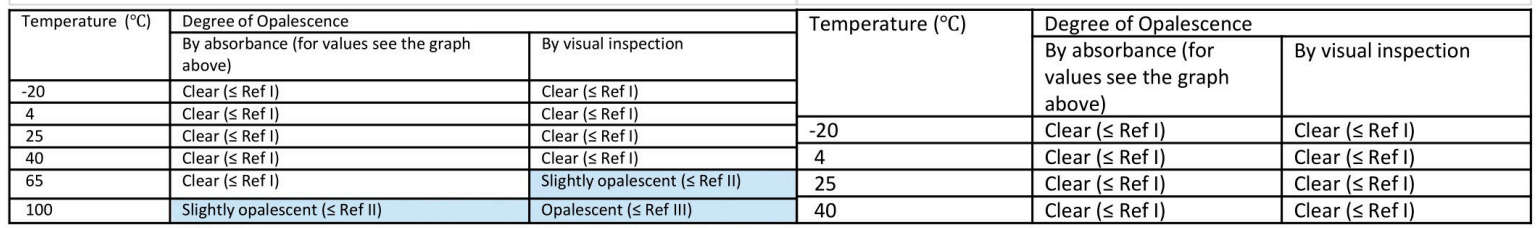

Figure 2. (a) Mean absorbance at $350 \mathrm{~nm}$ plotted against temperature $\left({ }^{\circ} \mathrm{C}\right)$ after insulin $(0.2 \mathrm{~mL}$, $10 \mathrm{mg} / \mathrm{mL}$ ) was stored at $-20{ }^{\circ} \mathrm{C}, 4{ }^{\circ} \mathrm{C}$ (control), $25^{\circ} \mathrm{C}, 40{ }^{\circ} \mathrm{C}, 65^{\circ} \mathrm{C}$ and $100{ }^{\circ} \mathrm{C}$ for 24 hours and diluted to $0.2 \mathrm{mg} / \mathrm{mL}$ for analysis. Data points shown are the mean of $\mathrm{n}=3$ measurements, with error bars indicating the standard deviations on these values. Tables give comparisons between the degrees of opalescence obtained by visual inspection and the instrumental method (absorbance at $350 \mathrm{~nm}$ ). (b) Mean absorbance at $350 \mathrm{~nm}$ plotted against temperature $\left({ }^{\circ} \mathrm{C}\right)$ after $3.5 \mathrm{mg} / \mathrm{mL}$ of insulin was stored at $-20{ }^{\circ} \mathrm{C}, 4{ }^{\circ} \mathrm{C}$ (control), $25^{\circ} \mathrm{C}$ and $40^{\circ} \mathrm{C}$ for 30 minutes. Data points shown are the mean of $\mathrm{n}=3$ measurements, with error bars indicating the standard deviations on these values.

DLS was used to provide information on the size of any potential insulin aggregates. Depending on the environmental storage conditions, insulin may exist as an equilibrium mixture of monomeric $(\mathrm{d}=2.8 \pm 0.3 \mathrm{~nm})$, dimeric $(\mathrm{d}=3.6 \pm 0.6 \mathrm{~nm})$, tetrameric $(\mathrm{d}=4.2 \pm 0.7 \mathrm{~nm})$ and hexameric $(\mathrm{d}=5.2 \pm 0.1 \mathrm{~nm})$ states in the solution [22,30,32]. For samples stored for 24 hours, the first peak and major peak observed was at $\mathrm{d}=4.85-5.61 \mathrm{~nm}$ for $\leq 40{ }^{\circ} \mathrm{C}$ (Figure 3a), indicating that the reversible equilibrium mixture had been established by the detection of tetramers and hexamers in the solution. Such small aggregates are commonly observed in pharmaceutical grade insulin samples and as the aggregation equilibrium for these small structures is reversible, the presence of tetramers and hexamers has no impact on the stability and efficacy of insulin solutions for injection. Beyond $40{ }^{\circ} \mathrm{C}$, there was a shift of the major peak from size $<10 \mathrm{~nm}$ to size $>10 \mathrm{~nm}$ (outside the size range of native insulin). Peaks were observed at sizes $>1000 \mathrm{~nm}$ for $-20^{\circ} \mathrm{C}, 4{ }^{\circ} \mathrm{C}$ and $40^{\circ} \mathrm{C}$. When DLS was repeated with identical insulin solutions but not filtered before analysis (Supplementary Materials S3), no peaks were observed at sizes $>1000 \mathrm{~nm}$, indicating that the larger aggregates formed post filtration. The process of filtration subjects aqueous dispersions of proteins to high shearing forces, which result in rapid self-aggregation and eventual precipitation [33]. This has been observed for insulin, where the shear forces alter the stable three-dimensional structure of the peptide exposing hydrophobic parts of the insulin molecule to water, this drives the self-aggregation process towards large fibrils which eventually precipitate $[34,35]$. For particles in the sub $100 \mathrm{~nm}$ region filtration is recommend prior to DLS analysis to remove any potential contamination, e.g., dust particles. This filtration did not affect the active smaller insulin aggregates, tetramers and hexamers, because the same mean size and distribution of peaks, close to $5 \mathrm{~nm}$, was 
observed for both the filtered and unfiltered insulin samples. When diluted to the pharmaceutical equivalent concentration of $3.5 \mathrm{mg} / \mathrm{mL}$, insulin solutions stored for 30 minutes showed a major peak $<10 \mathrm{~nm}(\mathrm{~d}=4.19-4.85 \mathrm{~nm})$ for all storage temperatures indicating a stable insulin solution containing predominately tetramers. (Figure $3 b$ ). No peak was observed at $>10 \mathrm{~nm}$ except for $-20{ }^{\circ} \mathrm{C}$.
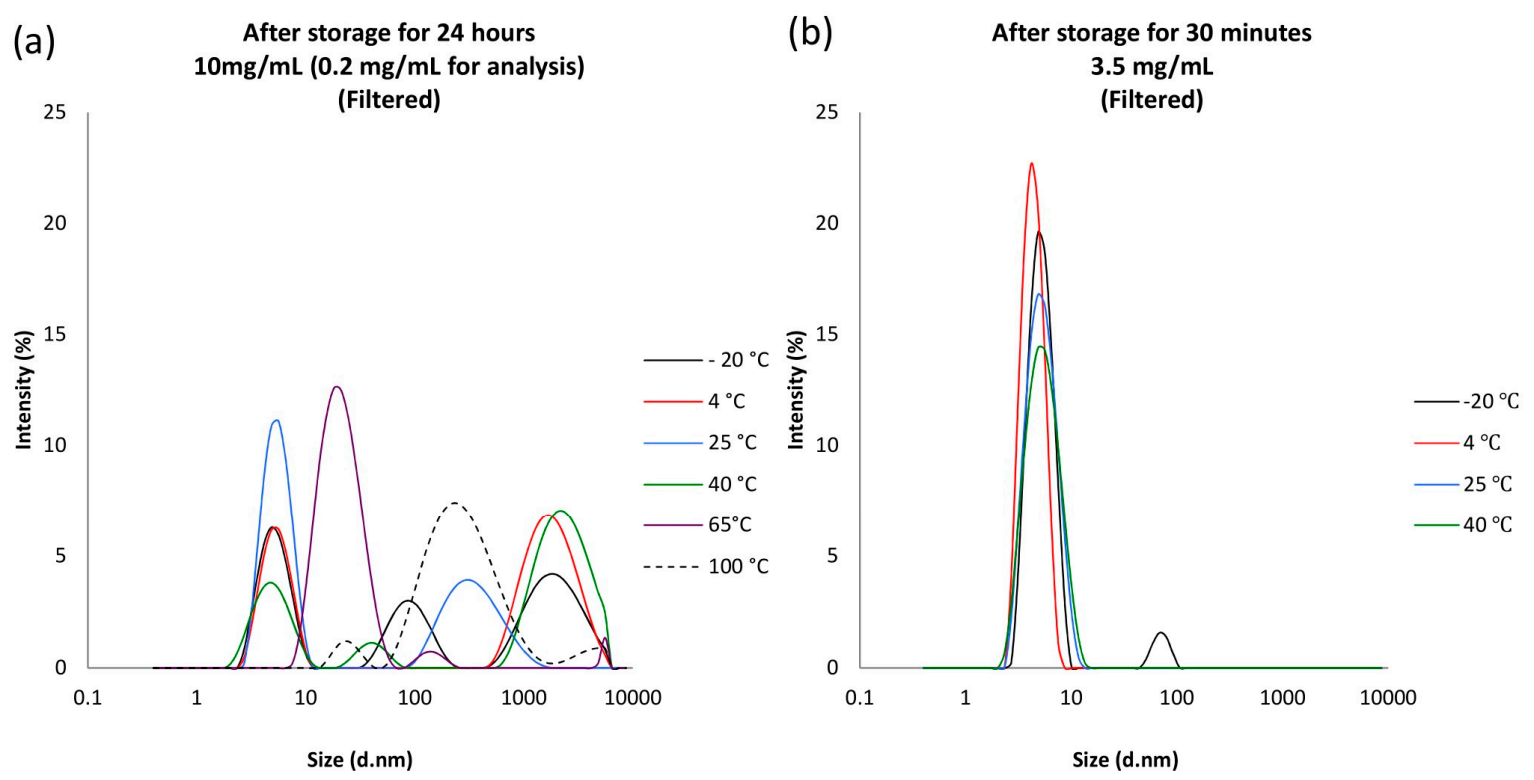

Figure 3. (a) Intensity (\%) plotted against particle size, (diameter in $\mathrm{nm}$ ) after insulin $(0.2 \mathrm{~mL}, 10 \mathrm{mg} / \mathrm{mL}$ ) was stored at $-20{ }^{\circ} \mathrm{C}, 4{ }^{\circ} \mathrm{C}$ (control), $25^{\circ} \mathrm{C}, 40^{\circ} \mathrm{C}, 65^{\circ} \mathrm{C}$ and $100{ }^{\circ} \mathrm{C}$ for 24 hours and diluted to $0.2 \mathrm{mg} / \mathrm{mL}$ for analysis. Samples were filtered with a $0.45 \mu \mathrm{m}$ syringe filter before analysis. (b) Intensity (\%) plotted against particle size (diameter in $\mathrm{nm}$ ) after insulin $(10 \mathrm{~mL}, 3.5 \mathrm{mg} / \mathrm{mL})$ was stored at $-20{ }^{\circ} \mathrm{C}$, $4{ }^{\circ} \mathrm{C}$ (control), $25^{\circ} \mathrm{C}$ and $40{ }^{\circ} \mathrm{C}$ for 30 minutes. Samples were filtered with a $0.45 \mu \mathrm{m}$ syringe filter before analysis.

\subsection{Effects of Vibration on Insulin}

The agitation frequencies produced by the vortex mixer were observed to be directly proportional to the vibration frequencies measured by the VibroChecker (Figure 4a); this relationship validated the use of the vortex mixer as a method to produce controlled vibration. Slight deviation from the gradient of one is attributed to the dampening effect by the supporting cardboard plate during vibration measurement. The $19 \mathrm{~Hz}$ measured by the VibroChecker when the vortex mixer was switched off, 0 agitation frequency, was assumed to be background noise/background vibration within the building, as the intensity of this signal was almost negligible $(0.01 \mathrm{~g})$.

All insulin samples remained clear after agitation at different frequencies for 30 minutes passing the BP test for insulin injections. It should be noted that an increasing froth formation was observed as agitation frequency increased (Figure $4 \mathrm{~b}$ ). There was an increase in absorbance at $350 \mathrm{~nm}$ with the increase in agitation frequency. Although all have passed the BP test, the differences in absorbance readings between $0 \mathrm{~Hz}$ (control) and all agitation frequencies were significant $(p<0.05)$. When tested at the pharmaceutical equivalent concentration of $3.5 \mathrm{mg} / \mathrm{mL}$, absorbance readings at all agitation frequencies were systematically higher than $0.5 \mathrm{mg} / \mathrm{mL}$ but the trends shown were similar (Figure 4c). The agreement of results between visual inspection and instrumental method for insulin samples at both concentrations is shown in the table (Figure 4c). 
(a)

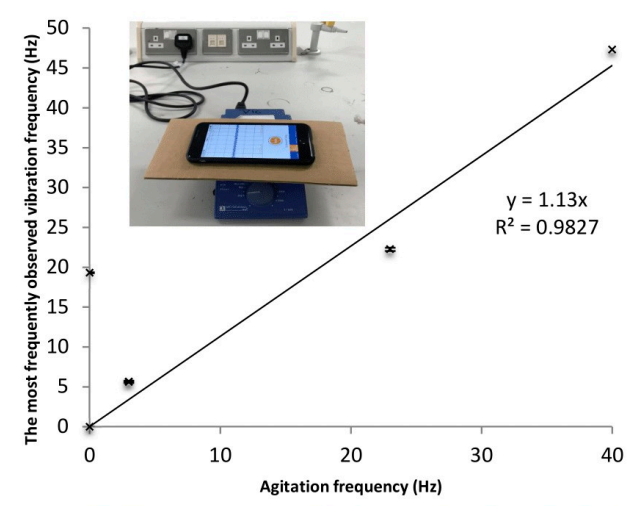

(b)

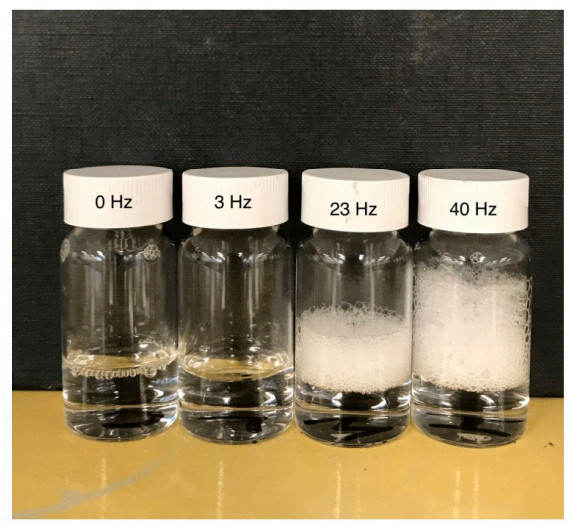

(c)
After agitation for $\mathbf{3 0}$ minutes

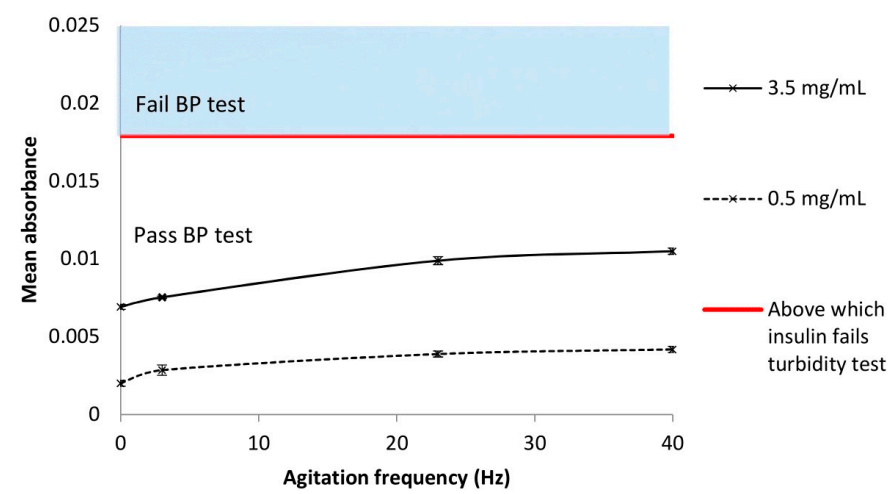

\begin{tabular}{|c|c|c|c|}
\hline \multirow{2}{*}{$\begin{array}{l}\text { Agitation } \\
\text { speed (rpm) }\end{array}$} & \multirow{2}{*}{$\begin{array}{l}\text { Agitation } \\
\text { frequency } \\
(\mathrm{Hz})\end{array}$} & \multicolumn{2}{|c|}{ Degree of Opalescence } \\
\hline & & $\begin{array}{l}\text { By } \\
\text { absorbance } \\
\text { (for values } \\
\text { see the graph } \\
\text { above) }\end{array}$ & $\begin{array}{l}\text { By visual } \\
\text { inspection }\end{array}$ \\
\hline 0 & 0 & Clear ( $\leq$ Ref I) & Clear ( $\leq$ Ref I) \\
\hline 200 & 3 & Clear ( $\leq$ Ref I) & Clear ( $\leq$ Ref I) \\
\hline 1400 & 23 & Clear $(\leq$ Ref I) & Clear ( $\leq \operatorname{Ref} \mathrm{I})$ \\
\hline & & & \\
\hline
\end{tabular}

Figure 4. (a) The most frequently observed vibration frequency $(\mathrm{Hz})$ plotted against agitation frequency $(\mathrm{Hz})$. Data points shown are the mean of $\mathrm{n}=3$ measurements, with error bars indicating the standard deviations on these values. (b) Visual appearances after insulin $(10 \mathrm{~mL}, 3.5 \mathrm{mg} / \mathrm{mL})$ was agitated at $0 \mathrm{~Hz}$ (control), $3 \mathrm{~Hz}, 23 \mathrm{~Hz}$ and $40 \mathrm{~Hz}$ at $25{ }^{\circ} \mathrm{C}$ (room temperature) for 30 minutes. (c) Mean absorbance at $350 \mathrm{~nm}$ plotted against agitation frequency $(\mathrm{Hz})$. Data points shown are the mean of $\mathrm{n}=3$ measurements, with error bars indicating the standard deviations of these values. The table gives comparison between the degrees of opalescence obtained by visual inspection and the absorbance for insulin at both concentrations $(0.5 \mathrm{mg} / \mathrm{mL}$ and $3.5 \mathrm{mg} / \mathrm{mL})$.

A series of vibration measurement tests were performed by securing the phone operating the VibroChecker app onto the drone in the same way as the Actrapid insulin samples would be attached in subsequent flight experiments. In these tests, the vibration frequency during vertical launching and landing was $0.1 \mathrm{~Hz}$. When flown forward, the most frequently observed vibration frequency was 3.4 Hz during initiation (transition from launching to stable flight) and $0.1 \mathrm{~Hz}$ in-flight (Supplementary Materials S5). When $3.5 \mathrm{mg} / \mathrm{mL}$ insulin was agitated at $3 \mathrm{~Hz}$ for 30 minutes, the sample passed the BP test with no froth (Figure $4 \mathrm{~b}$ ). However, the difference in absorbance readings between control and $3 \mathrm{~Hz}$ was small but significant $(p<0.01)$.

In the DLS measurements, a major peak was observed below $10 \mathrm{~nm}, \mathrm{~d}=4.85 \mathrm{~nm}$, for $0.5 \mathrm{mg} / \mathrm{mL}$ insulin at ambient conditions without exposure to the vortex mixer $(0 \mathrm{~Hz})$ and for samples subjected to all the different agitation frequencies (Figure 5a). Filtration, as described earlier, generated large aggregates of size $>1000 \mathrm{~nm}$ for 3 and $23 \mathrm{~Hz}$. When repeated with insulin samples unfiltered before analysis (Supplementary Materials S3), these peaks were not observed. When tested at $3.5 \mathrm{mg} / \mathrm{mL}$, a single peak was observed below $10 \mathrm{~nm}(\mathrm{~d}=4.85-5.61 \mathrm{~nm})$ for all agitation frequencies (Figure $5 \mathrm{~b}$ ). No peaks were observed at above $10 \mathrm{~nm}$, except for 23 and $40 \mathrm{~Hz}$. 


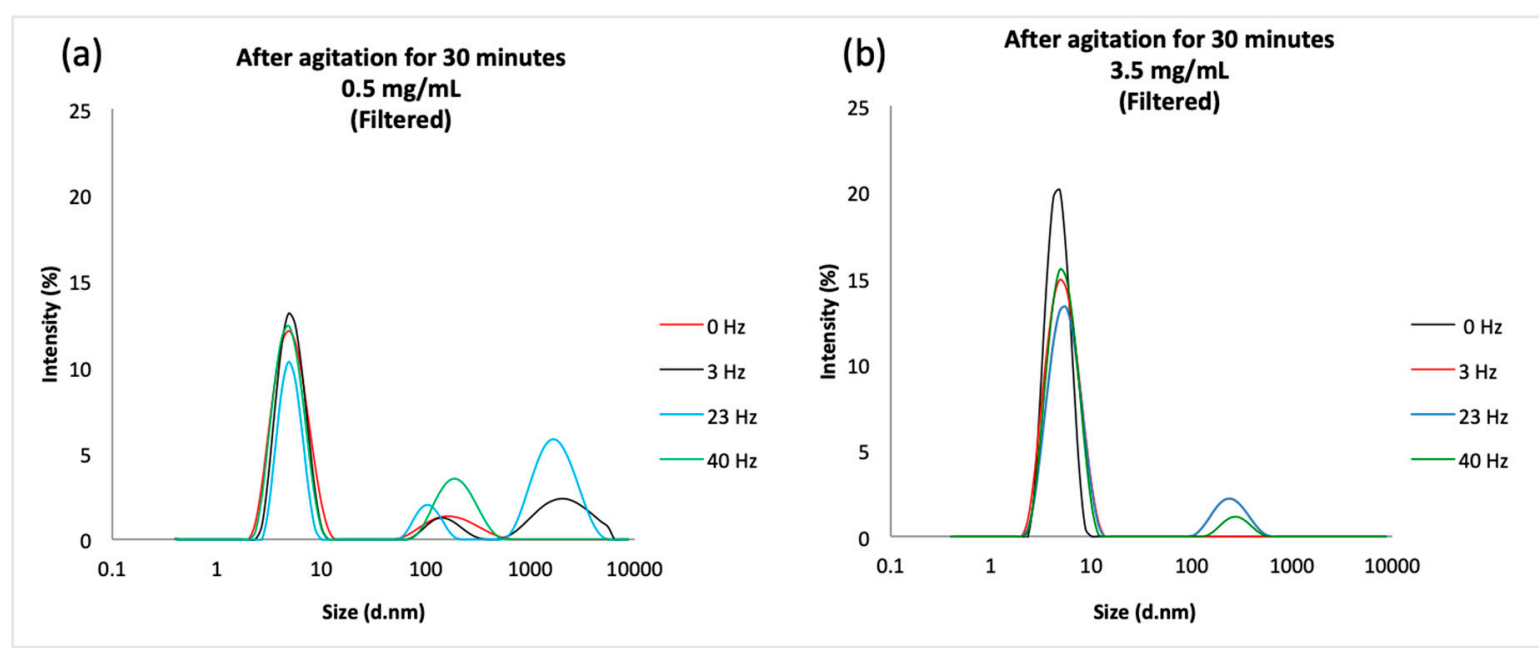

Figure 5. (a) Intensity (\%) plotted against particle size, (diameter in $\mathrm{nm}$ ) after insulin $(5 \mathrm{~mL}, 0.5 \mathrm{mg} / \mathrm{mL}$ ) was agitated at $0 \mathrm{~Hz}$ (control), $3 \mathrm{~Hz}, 23 \mathrm{~Hz}$ and $40 \mathrm{~Hz}$ at $25^{\circ} \mathrm{C}$ (room temperature) for 30 minutes. Samples were filtered using a $0.45 \mu \mathrm{m}$ syringe filter before analysis. (b) Intensity (\%) plotted against particle size (diameter in $\mathrm{nm}$ ) for $10 \mathrm{~mL}$ of $3.5 \mathrm{mg} / \mathrm{mL}$ insulin agitated at $0 \mathrm{~Hz}$ (control), $3 \mathrm{~Hz}, 23 \mathrm{~Hz}$ and $40 \mathrm{~Hz}$ at $25^{\circ} \mathrm{C}$ (room temperature) for 30 minutes. Samples were filtered using a $0.45 \mu \mathrm{m}$ syringe filter before analysis.

\subsection{Preliminary Payload and Flight Time Test}

Preliminary tests were performed to provide guidance for the maximum payload, range and flight time and formed the basis of the test flight protocols used in this study. Line of sight was maintained at all times. Sets of masses of $41.4 \mathrm{~g}$ (low), $81.2 \mathrm{~g}$ (medium) and $194.6 \mathrm{~g}$ (high) were securely attached on top of the drone using a polypropylene-based sealing tape. Battery level $>30 \%$ was set as the safe working range. Before each payload test, the battery was fully charged $(100 \%)$.

For preliminary indoor testing, the loaded drone was launched and allowed to hover at a height of $1.2 \mathrm{~m}$. The time taken for battery level reduction from $100 \%$ to $30 \%$ was recorded. For preliminary outdoor testing $\left(0-9{ }^{\circ} \mathrm{C}\right.$, wind speed $1-3 \mathrm{mph}$, relative humidity $76-100 \%$, 1024-1026 mbar) [28], loaded drone was ascended to the test altitude of $10 \mathrm{~m}$ and instructed to orbit [14] around a fixed pole (radius $=5 \mathrm{~m}$, constant speed $1.5 \mathrm{~m} / \mathrm{s}$ ). As battery level reached $30 \%$, drone was instructed to land. The time taken for battery level reduction was recorded. These tests were conducted to determine the edge of failure for battery life.

As the mass of load is increased, the time taken for battery level to reach $30 \%$ decreased exponentially (Figure 6). When hovering indoors with high load, there was a $40 \%$ decrease compared to no load and an alert indicating maximum motor speed reached was shown before the battery level reached $30 \%$. Hence, the maximum payload for safe use was set at $<200 \mathrm{~g}$. When orbiting outdoors, there was an apparent longer battery life compared to hovering indoors, but the differences were insignificant for medium $(p=0.17)$ and high mass $(p=0.08)$ loads but significant for low mass and without loads $(p<0.05)$. 


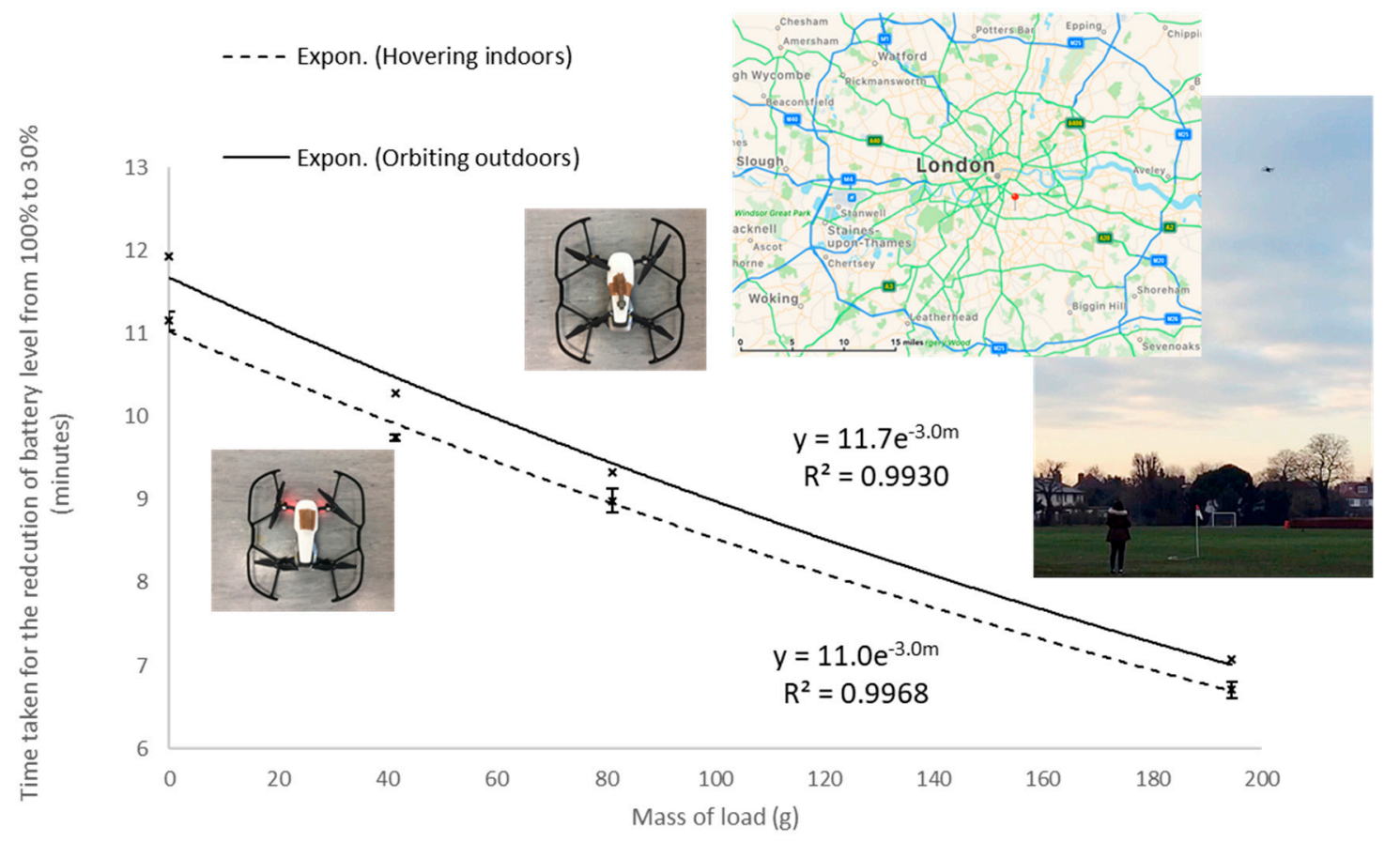

Figure 6. Time taken for the reduction of battery level from $100 \%$ to $30 \%(\mathrm{~min})$ plotted against $\mathrm{m}$ (mass of load in $\mathrm{kg}$ ). The exponential regression for drone hovering indoors: time $=11.0 \mathrm{e}^{-3.0 \mathrm{~m}}$ $\left(R^{2}=0.9968\right)$. Data points shown are the mean of $n=3$ measurements, with error bars indicating the standard deviations of these values. The exponential regression for drone orbiting outdoors: time $=11.7 \mathrm{e}^{-3.0 \mathrm{~m}}\left(\mathrm{R}^{2}=0.9930\right)$. Data points shown are $\mathrm{n}=1$. Demonstration of the drone orbiting outdoors at height $=10 \mathrm{~m}$, radius $=5 \mathrm{~m}$, speed $=1.5 \mathrm{~m} / \mathrm{s}$ around a fixed pole was performed at The Griffin Sportsground, flight site, London, SE21 7AL, United Kingdom.

\subsection{Drone Flights Involving Pharmaceutical Insulin (Actrapid)}

All three Actrapid samples flown over $0.81 \pm 0.18 \mathrm{~km}$, and in their original packaging, were clear and passed the BP turbidity test with slight bubble formation (Figure $7 \mathrm{~b}, \mathrm{c}$ ). There was insignificant difference in absorbance between the control (flight site) and the flown samples ( $p=0.54$ ) as well as between the control (flight site) and the control (fridge) $(p=0.89)$. In the DLS measurements, one major peak was observed below $10 \mathrm{~nm}(\mathrm{~d}=4.19-4.85 \mathrm{~nm})$ for all controls and flown samples (Figure $7 \mathrm{~d}$ ) indicating the presence of insulin tetramers. Unlike analytical grade insulin, samples were unfiltered before analysis to avoid any peaks at sizes $>1000 \mathrm{~nm}$ induced by the shear forces associated with filtration. However, a low intensity peak was observed above $1000 \mathrm{~nm}$, which was a constant in all samples and controls, thus it was inherent in the original formulation and was not formed as a result of the drone transport. All of the samples passed the pharmacopeia stability tests, thus insulin quality, or more specifically the quality of the medicinal product, Actrapid $3.5 \mathrm{mg} / \mathrm{mL}$ was not affected by drone delivery. 
(a)

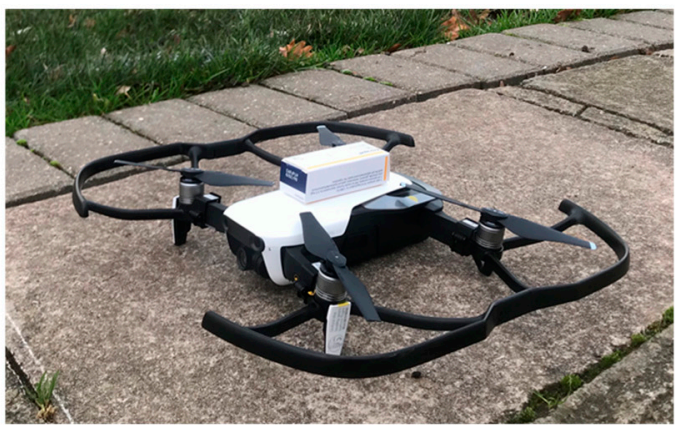

(c)

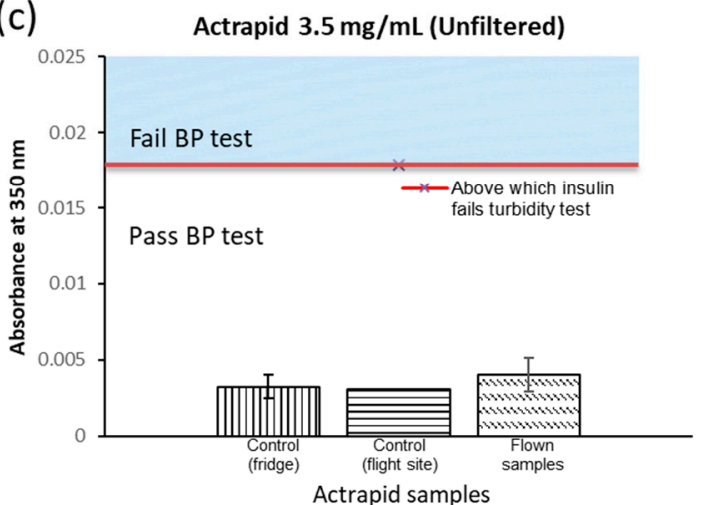

(b)
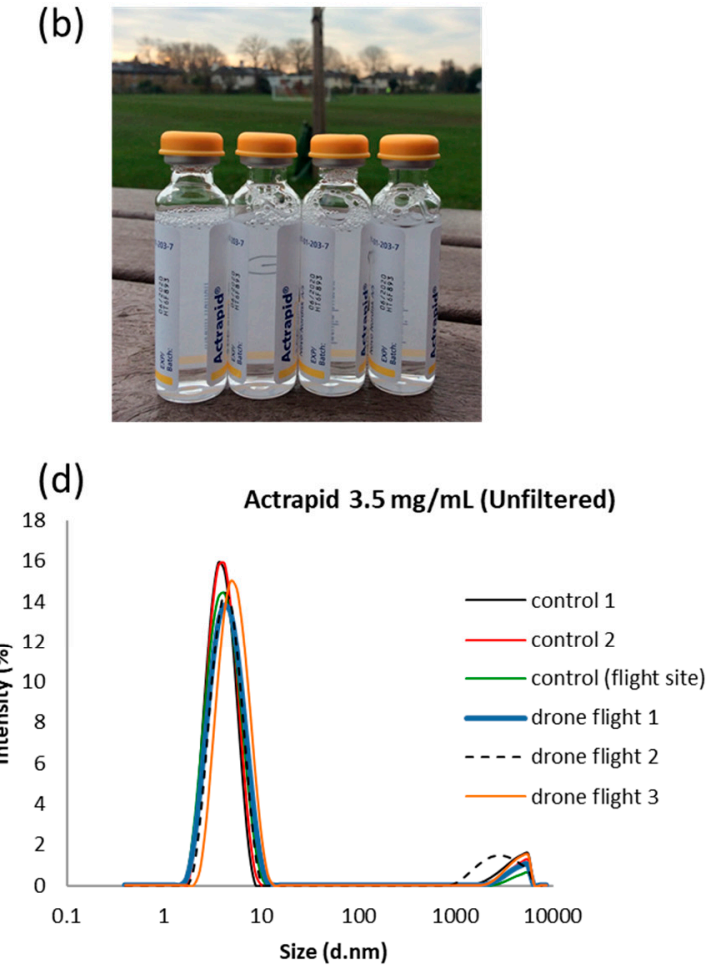

Figure 7. (a) Actrapid in its original packaging was securely attached onto the Mavic Air. (b) Visual appearances of Actrapid after flight ( $9 \pm 2$ minutes, $n=3$ control on the left). (c) Mean absorbance at $350 \mathrm{~nm}$ plotted against the flown and not flown Actrapid. Data points shown are the mean of $\mathrm{n}=2$ measurements for control (fridge), $n=1$ measurement for control (flight site) and $n=3$ measurements for flown samples, with error bars indicating the standard deviations on these values. (d) Intensity (\%) plotted against particle diameter, given in $\mathrm{nm}$, (d.nm) for three flown Actrapid samples, one control (brought to flight site) and two controls (from fridge).

\section{Discussion}

The formazin turbidity standards, the basis of the pharmacopoeia quality tests, were a dispersion of small colloidal particles. The principle of turbidity measurement is based on the attenuation of incident beams due to light scattering by particles [26]. Thus, an increase in absorbance at $350 \mathrm{~nm}$ was related to the increase in the concentration of formazin particles. The robustness of formazin as an effective turbidity standard was clearly shown from the repeatability of absorbance readings (Supplementary Materials S1). If medicines are to be regularly delivered by drones, then their quality tests upon receipt must be simple to perform, non-destructive and easy to interpret. The British Pharmacopoeia degree of opalescence test based on formazin meets these criteria, as it is based on the mixing of liquids and visual inspection of the intact glass vial [24], which further supports the potential of insulin to be transport by drones.

Apart from the formation of large fibrils, insulin solutions are also known to form much smaller aggregates in the nm region [26], an order of magnitude smaller than the formazin particles [36,37]. DLS was used to complement the UV turbidity analysis as it is a sensitive method for measuring such small-sized aggregates, 1 to $450 \mathrm{~nm}$ in diameter [38,39]. The time-dependent fluctuations in the scattering intensity as a result of Brownian motion are measured by DLS, the frequency of these fluctuations are used to determine particle diffusion coefficients and particle size [38]. Based on Rayleigh's approximation, the scattering intensity of a particle is proportional to the sixth power of its diameter [38]. DLS successfully showed the presence of the reversible smaller aggregates in all of the insulin solutions investigated, but where larger fibril aggregates appear, the BP opalescence test was definitive for identifying failing samples as a result of this physical instability. 
The purpose of investigating analytical grade insulin was to develop stability testing protocols that would mimic the range of conditions possible during drone flight. Extreme temperatures (e.g., $100^{\circ} \mathrm{C}$ ) and storage times (24 hours) were also applied to guarantee at least some failures of insulin stability and thus validate the quality tests. It was not possible to purchase analytical grade insulin at the same concentration as that found in Actrapid, the analytical grade required dilution. Ultra-purewater ( $\mathrm{pH}$ 7) was used to minimise heterogeneous nucleation [27] and mimic physiological $\mathrm{pH}$; however, insulin solutions for injection are typically formulated in mildly acidic conditions to maintain solubility. Although a pH of 7 is above insulin's isoelectric point at $\mathrm{pH}$ 5.4, where the molecule is not charged, the authors investigated the effect of dilution by acid $(0.01 \mathrm{M} \mathrm{HCl})$ on the representative stability samples to allow comparison with the insulin solutions prepared using ultra-pure water (Supplementary Materials S2), which demonstrated no effect on the degree of opalescence.

Physical instability, i.e., irreversible aggregation, inactivates insulin [40]. High temperatures facilitate protein unfolding, and increase the diffusion and collision rates of the unfolded insulin molecules. Thus, at high temperatures an activation energy barrier is overcome and large aggregates form [30,41], as was observed for insulin solutions held at 65 and $100^{\circ} \mathrm{C}$. The mechanism of aggregation and eventual precipitation of insulin is complex, but it may be simplified by the following schematic.

$\operatorname{Hexamer}_{(\mathrm{aq})} \leftrightharpoons \operatorname{Tetramer}_{(\mathrm{aq})} \leftrightharpoons \operatorname{Dimer}_{(\mathrm{aq})} \leftrightharpoons \operatorname{Monomer}_{(\mathrm{aq})} \rightarrow \operatorname{Unfolded~Monomer}_{(\mathrm{aq})} \rightarrow \operatorname{Fibril}_{(\mathrm{s})}$

High temperatures, shear stress, exposure to vibration/agitation, increase in ionic strength and contact with hydrophobic surfaces induce conformational change within the insulin molecule present in aqueous solution, leading to the unfolding of the insulin monomer [42]. The unfolded monomers are not stable in water, and to lower the free energy of the system, they come together to form a fibril [42]. Fibrils contain many hundreds of insulin molecules, where the insulin is irreversibly bound together into structures many mm long that eventually precipitates out of the solution. After storage at 65 and $100{ }^{\circ} \mathrm{C}$ for 24 hours, such fibrils are easily detected by visual inspection (Figure 1a). To avoid the formation of fibrils, zinc ions in the form of zinc chloride are often added to pharmaceutical grade formulations of insulin to increase stability, and this is the case for Actrapid. Zinc ions stabilise the formation of the reversible smaller insulin aggregates, namely tetramers and hexamers. Insulin formulations containing these structures are regarded as stable, since they are in equilibrium with the monomeric form of insulin. Tetramers and hexamers were detected in the drone-delivered Actrapid and all solutions of insulin stored at or below $40^{\circ} \mathrm{C}$. The analytical grade of insulin used for the storage experiments did not contain zinc ions. Even after storage at $40^{\circ} \mathrm{C}$ for 24 hours insulin fibrils were not detected in these samples, indicating that potentially less stable formulations of insulin could also be transported by a drone.

Settling of aggregates in solution [43] may have contributed to the slightly lower absorbance values obtained than expected for insulin stored at $65{ }^{\circ} \mathrm{C}$, giving results where insulin passed the turbidity test by absorbance but not by visual inspection. Whereas the large number of fibrils, i.e., precipitated insulin, after storage at $100{ }^{\circ} \mathrm{C}$ were easily detected in both the visual and UV-based turbidity assays. Although insulin stored at $-20{ }^{\circ} \mathrm{C}$ passed the BP test and showed insignificant difference in absorbance readings with the control $(p=0.71)$, studies report that freeze-thawing compromises insulin quality $[41,44]$. Freezing induces aggregation by local concentration of protein, causing a variation in protein distribution throughout the frozen mass [41,45]. This can be observed in the DLS measurements with the detection of a small population of particles close to $100 \mathrm{~nm}$ for the $3.5 \mathrm{mg} / \mathrm{mL}$ concentrations of insulin stored at $-20{ }^{\circ} \mathrm{C}$ for $30 \mathrm{mins}$. Thus, when flying insulin samples by drone in colder environments, or at high altitude, partial freezing within the solutions needs to be considered.

The simulated laboratory tests investigating the effects of temperature and vibration explored the edge of failure and were used to validate the flight-testing experiments. The temperature range of interest for drone delivery is -20 to $+40{ }^{\circ} \mathrm{C}$ [46]. The storage temperature of $-20{ }^{\circ} \mathrm{C}$ simulated drone delivery on days with sub-zero temperatures or while flying to reach, for example, communities in the 
Alps at high altitudes [47]. While the $40{ }^{\circ} \mathrm{C}$ storage conditions simulated drone delivery in countries with hot climates. As insulin is highly temperature-sensitive, the development of on-board active cooling or heating devices will be important for the maintenance of insulin quality and compliance with the storage requirement made by the manufacturer of between 2 and $8{ }^{\circ} \mathrm{C}$ [48]. However, our work indicates that higher storage temperatures for insulin over short periods may be acceptable, as supported by the samples stored at $40{ }^{\circ} \mathrm{C}$ for 30 minutes passing the BP test, which reinforces the potential for safe delivery of insulin by drones in hotter climates.

The operating temperature of the DJI Mavic air drone is between 0 to $+40^{\circ} \mathrm{C}$. For specific missions, imaging Arctic environments and surveying remote infrastructures for example, several commercial drones have operated successfully at temperatures well below zero, (e.g., a DJI phantom 4 was flown at a temperature approximately $-10^{\circ} \mathrm{C}$ at the Tarfala Research Station Sweden [49]. The major limitations for these applications are the reduction in working time for the lithium-based batteries. Improvements in battery technology is ongoing, thus in this study it was important to simulate in the laboratory the impact of colder temperatures (e.g., $-20^{\circ} \mathrm{C}$ ) when considering the delivery of medicines using drones in potentially colder climates. The upper temperature limit of stability testing is set at $+40^{\circ} \mathrm{C}$ in pharmaceutical regulations; however, in very extreme environments, tropical climates for example, drones will experience temperatures closer to $+50{ }^{\circ} \mathrm{C}$ or above. Thus, the temperature stressing experiments reported in this study covered such extreme values.

Agitation by a vortex mixer was performed to model the impact of vibrations potentially generated by drone flight. As the agitation frequency increased, the major peaks observed in the DLS remained close to $4.85 \mathrm{~nm}$, which corresponded to the tetrameric form of insulin previously measured by Pease et al. [32]. Hence, it can be deduced that insulin remained stable after agitation. Furthermore, since insulin solutions subjected to $3 \mathrm{~Hz}$ at $25{ }^{\circ} \mathrm{C}$ for 30 minutes passed the BP turbidity test, and $3 \mathrm{~Hz}$ was close to the maximum frequency observed in the drone flight tests, it would appear that vibration is not an issue for the delivery of Actrapid using the small DJI Mavic Air drone. However, in the vortexing experiments and in the drone flight tests, frothing was observed at the surface of the solutions. Intense shaking induces shear and cavitation within solutions, where rapid collapse of the bubbles formed produces shock waves and turbulent flow [30]. This causes the protein molecules to realign at the air-water interface and expose the inner hydrophobic core of protein to the air, causing conformational changes to insulin monomers from a predominantly $\alpha$-helical state to a $\beta$-sheet rich conformation $[43,50]$. Interactions between partially unfolded monomers then shift the aggregation equilibrium towards the formation of fibrils [50]. Even though such fibril formation was not observed in the Actrapid solutions flight tested here, a small amount of froth formation was observed. Thus, measuring vibrations within liquid-based protein medications delivered by a drone still needs to be considered [51,52]. Possible approaches to reduce the impact of in-flight vibration include head space reduction above solutions in vials or the use of packaging materials that do not transmit vibration [52]. During normal flight, drones are designed to have minimal vibration to increase efficiency and maintain stability [52,53], this may not be the case during launch or as a result of a collision or even crash landing. Innovative dampening systems are employed to protect more advanced drones from sudden vibrations or collisions, for example, the PackDrone from Dronistics which contains the drone within a cage [51]. In case of collision, the cage works as a damper to absorb energy from the shock and protect packages [52].

The vibrations suffered by medicines transported using rotor-based drones could be minimized by increasing the number of rotors in order to increase stability, noting that the performance of the blades must be tuned accurately. Alternatively, the gimbal technology used for camera mounts could easily be exploited for the transport of medicines. In the case of fixed-wing drones, smooth take off and landing surfaces would be optimal for reducing vibration. There is very limited data available providing the vibrations experienced by packages transported using rotor-based drones, thus a good estimate of the potential exposure is given in Supplementary Materials Figure S4, where the most significant vibrations range between 0.1 and $10 \mathrm{~Hz}$. 
The drone used here was compact ( $430 \mathrm{~g}$ ) compared to the drones currently designed for the transportation of parcels [52,53], but the approach towards safe flight time testing is transferable from our study to larger systems. Medicines are potentially dangerous, thus setting the battery limit of $30 \%$ is recommended to allow the safe landing for a drone transporting a medicine. Determining the relationship between the mass of the load carried and the safe flight time, or safe range, is vital as different packaged medicines have different gross weights. Modelling this relationship is essential for mapping the edge-of-failure and thus aiding in the selection of the best drone for the required delivery task. The time taken for battery level reduction from 100\% to 30\% decreased exponentially with the increase in mass of loads (Section 3.4). Greater power was needed to lift heavier loads, hence the reduced flight time [54]. Although flight times, speed and distance covered will vary depending on atmospheric conditions, for example wind speed, it was encouraging that the indoor and outdoor testing gave similar exponential decays between safe flight time and mass of load. A study on blood products transportation in Baltimore, Maryland discovered that temperature and atmospheric pressure change with altitude are small, $0.68^{\circ} \mathrm{C} / 100 \mathrm{~m}$ and $12 \mathrm{mbar} / 100 \mathrm{~m}$, respectively [14]. The maximum allowable altitudes for drone flights are set very conservatively; in the United Kingdom this is $400 \mathrm{ft}$ or approximately $120 \mathrm{~m}$. Thus, the impact of altitude on the temperature and pressures experienced by a medicine on board a drone is expected to be limited under current regulations for the United Kingdom. Applying the exponential equation for safe flight time determined from the outdoor experiments, (Section 3.4), the maximum safe range to fly an Actrapid package ( $23.8 \mathrm{~g}$ ) was just under $1 \mathrm{~km}$. This was much lower than the manufacturers claim of a $4 \mathrm{~km}$ range unloaded, but it should be noted that DJI Mavic Air is not designed for transporting packages, and the experimental flights involved orbits around a fixed point rather than straight-line flights. Tight circular motion will reduce the efficiency of a drone due to the extra centrifugal forces. The flight speed of $1.5 \mathrm{~m} / \mathrm{s}$ and wide loop of $10 \mathrm{~m}$ used here indicate that these additional forces are likely to be low. For the transport of Actrapid between King's College Hospital in London and local clinics, a $1 \mathrm{~km}$ radius would be useful as this encompasses over 10 GP surgeries and pharmacies combined; but for the delivery of Actrapid to other locations a more powerful drone is required. Current drone designs suggest safe flight times for such applications to be close to 30 minutes [12]. The outcome of this study indicates that insulin solutions transported for these drone flight times would arrive in a stable condition and pass the BP quality test.

Many of the barriers to the routine delivery of medicines by drones are still in place but the study reported here shows that this technology, after the required testing and validation, has the potential to deliver sensitive peptide-based drugs. The future of clinically useful drone deliveries requires the relaxation of regulations around flying beyond the line of sight [14]. In Switzerland, drones have been approved to fly autonomously to carry blood products and cytostatic materials between hospitals in static routes since October 2017 [46]. However, the integration of drones into air traffic control systems remains unsolved [45], and authorisation of an approved route usually takes $\sim 8-18$ months [46]. Battery life is yet another barrier. According to Swiss Post, the current technology allows one battery to last for $20 \mathrm{~km}$ (speed $=1 \mathrm{~km} / \mathrm{min}$ ) [46]. Data loggers enabling live recording of the temperature of material have been developed to ensure the maintenance of the cold chain [46]. The temperatures measured by such studies were within the range of temperatures reported in this study. As drones are extremely weight-sensitive, the maximum payload will be reduced if on board active cooling systems have to be added [14,46]. A number of manufacturers are positive with respect to this issue as their technologies allow a payload capacity of $2 \mathrm{~kg}$, but the challenge is to design a larger carrier box to accommodate on board cooling devices $[46,53]$. Future developments could include drones with infrared/thermal imaging cameras [54] or directional microphones, enabling quick assessment of victims in emergency situations before dispensing the required medication [46,52]. Securing the supply chain to avoid drone-delivered medicines being redirected for illicit purposes is an issue that must be addressed. Initiatives such as on board anti-tamper monitoring aim to ensure security and authenticity of the supply chain [53]. 
Our study provides much needed stability data showing that drones have the potential to safely deliver medicines. Insulin is a very important medicine, but more studies are required that encompass a wider range of medicines that show promise for drone delivery. After discussing our work with pharmacists and clinical colleagues [55], it was agreed that the direction of travel should be towards medicines used for emergency situations. Many medicines make good candidates for delivery by drone (Table 2), for example; adrenaline, thrombolytics, nitroglycerin and beta blockers for cardiac arrests; vaccines for local outbreaks of disease; portable nebulizers in the case of severe asthma attacks; and antibiotics for suspected sepsis. Speed of delivery is the beneficial attribute provided by the drone. Interestingly, to avoid the creation of large stocks of opioids in care and private homes, when break through pain is registered by a patient undergoing palliative care, a quick delivery of the required medication at the required dose for the pain management specific to the patient's needs would avoid potential redirection and abuse of surplus opioid stocks.

Table 2. Other possible types of medicines that can be delivered by drones.

\begin{tabular}{|c|c|c|c|c|c|}
\hline Application & Clinical Need & $\begin{array}{l}\text { Medicinal Product } \\
\text { (Example) }\end{array}$ & Location & $\begin{array}{l}\text { Benefit of } \\
\text { Drone Use }\end{array}$ & Open Issues \\
\hline Emergency & Allergic reaction & Epi pen & Out of clinic & Rapid transfer & $\begin{array}{l}\text { Medicine } \\
\text { stability }\end{array}$ \\
\hline Emergency & Overdose & $\begin{array}{l}\text { Prothrombin } \\
\text { complex } \\
\text { concentrate }\end{array}$ & Out of clinic & Rapid transfer & $\begin{array}{l}\text { Medicine } \\
\text { stability }\end{array}$ \\
\hline Emergency & Cardiac arrest & $\begin{array}{c}\text { Adrenaline, } \\
\text { lidocaine, atropine }\end{array}$ & Out of clinic & Rapid transfer & Delivery speed \\
\hline Emergency & Asthma attack & $\begin{array}{c}\text { Salbutamol } \\
\text { Nebulizer }\end{array}$ & Out of clinic & Rapid transfer & Delivery load \\
\hline Emergency & Snake bite & Antivenom/antidotes & In field & $\begin{array}{l}\text { Remote } \\
\text { delivery }\end{array}$ & Range stability \\
\hline Emergency & Disease outbreak & Vaccine & In field & $\begin{array}{l}\text { Remote } \\
\text { delivery }\end{array}$ & Range stability \\
\hline Emergency & Suspected sepsis & I.V. antibiotics & In clinic & Rapid transfer & $\begin{array}{l}\text { Medicine } \\
\text { stability }\end{array}$ \\
\hline Emergency & Chemotherapy & $\begin{array}{c}\text { Short half-life } \\
\text { radionucleotide }\end{array}$ & In clinic & Rapid transfer & Security, safety \\
\hline Emergency & Burn debraiding & Live maggots & In clinic & $\begin{array}{l}\text { Centralised } \\
\text { supply }\end{array}$ & Range \\
\hline Emergency & Clotting agent & Live leaches & Out of clinic & $\begin{array}{c}\text { Centralised } \\
\text { supply }\end{array}$ & Range \\
\hline Palliative Care & $\begin{array}{l}\text { Dispensing } \\
\text { controlled drugs }\end{array}$ & $\begin{array}{l}\text { Injectable } \\
\text { medicines } \\
\text { (morphine) }\end{array}$ & Out of clinic & Control & Security, safety \\
\hline Diagnosis & $\begin{array}{c}\text { Specialised } \\
\text { diagnostic test }\end{array}$ & Blood, tissue, etc. & In clinic & $\begin{array}{l}\text { Centralised } \\
\text { supply }\end{array}$ & Safety, range \\
\hline Diagnosis & Nuclear imaging & $\begin{array}{l}\text { Short half-life } \\
\text { radionucleotide }\end{array}$ & In clinic & Rapid transfer & Security, safety \\
\hline
\end{tabular}

\section{Limitations and Opportunities}

The limitations of our study are concerned with the relatively small size of the drone used. Regulations prevented a large drone being flown in London, so only a small drone was used for the proof of concept. As stated, this was fit for the purpose of evaluating drone transport between hospitals and clinics within inner cities, where the flight paths are very short $(1 \mathrm{~km})$; but to improve, future work needs to investigate fixed-wing UAS and VTOL's that operate over much larger distances $(40 \mathrm{~km})$. It is to be expected that in-flight vibration will be different for these UAS compared to the quad-rotor 
drone used here, which further supports measuring in-flight vibration frequencies, as described in Sections 2.4 and 3.3 in this paper, when evaluating a specific VTOL for the delivery of liquid-based or fragile medicines. The study here investigated flying in orbits which is not representative of any typical UAS flight paths, especially over rural areas. However orbits are closer, in part, to the tight turns required for flight in some urban settings. Thus, the approach outlined in this study needs to be applied to medicines transported in a broader range of drones that have the capacity to fly a greater range missions that cover much longer distances, up to $40 \mathrm{~km}$.

Using real-life scenario dispatching drones, that fly beyond the visual line of sight (BVLOS) would not affect the recommendations generated in this paper, see Section 6.1, but the ranges of the critical process parameters used for stability simulation would have to be confirmed. For example, 6 and 8 rotor drones are more stable, and any medicine carried by them would be exposed to lower intensity vibrations than the quad drone used in the present paper. Real-world BVLOS missions using both rotor and fixed-wing UAS would additionally require data loggers placed in the packaging. Data loggers are commonly used in the supply chain for pharmaceuticals and record temperature, and some even vibration, over time. Such devices were precluded from this study because of the space available on the DJI Mavic Air drone, but for BVLO missions using larger drones these loggers would need to be carried onboard and within any additional packaging, to record any potential changes in temperature during the mission as a consequence of the greater flight range.

The length of the lab tests, 30 minutes, was set to mimic the typical maximum flight times of commercially available multi-rotor drones that take off and land vertically, a facility required for delivering medicines in urban environments. The drone flight tests presented here were conducted within the safe operating limits, i.e., flying from $100 \%$ battery charge level down to $30 \%$, to allow landing with absolutely no chance of drone failure. Once loaded the safe flight times reduced to 9 minutes. The 9-minute flight vs. the 30-minute lab tests may have introduced bias, for example, a 30-minute flight may have led to the freezing of the Actrapid sample, as the temperature over the flight path was between -1 and $0{ }^{\circ} \mathrm{C}$. Ice was not observed in the flight tests and is not expected to occur if the samples were flown for 30 minutes, as the zinc chloride present depressed the freezing point of the water in the samples. Although, the impact of freeze-thawing on insulin dispersions was fully explored in the lab and these samples still passed the BP quality tests. The vibration tests in the lab lasted for 30 minutes and were conducted at $25^{\circ} \mathrm{C}$. In the drone tests Actrapid was exposed to nine minutes of flight vibrations $(0.1$ to $3.4 \mathrm{~Hz})$ at -1 to $0{ }^{\circ} \mathrm{C}$. Degradation of insulin due to vibration requires insulin molecules to diffuse to the air-water interface and then unfold, both diffusion and molecular rotation are proportional with temperature, thus the chances of observing vibration initiated degradation would have been much lower in the drone flights compared to the lab tests. Thus, the lab tests were carried out for an extended time and over a wide range of vibrational frequencies in order to capture any potential vibrational degradation, none was observed.

\section{Conclusions}

In recent years, there is an increasing interest in drone delivery of medicines to remote areas. However, little has been reported about the feasibility and impact of drone delivery on medicines, hence the need for this study. The testing on human insulin has proven that insulin quality was maintained after exposure to environments that mimic a 30-minute drone delivery (temperatures -20 to $+40{ }^{\circ} \mathrm{C}$, vibration frequencies $0-40 \mathrm{~Hz}$ ). Following drone transportation, there was no adverse impact on Actrapid apart from slight bubble formation post flight. To the best of the authors' knowledge, this is the first successful testing of insulin quality flown by a drone, which gives supporting evidence that drone transportation of insulin is feasible from the point of view of pharmaceutical stability and maintenance of medicine quality. Hence, this research serves as a model for future studies investigating other types of medicines, environmental conditions or different drones. 


\subsection{Implications and Recommendations}

The authors recommend that when considering delivering medicines using a drone the following five tests need to be applied. (1) Considering the gross weight of the medicines to be transported, the safe flight time and safe range need to be determined. Testing the edge-of-failure by taking into account the likely variance of environmental conditions is required for the selection of the most appropriate drone. (2) A quality test for the medicine is required post delivery to ensure that the pharmaceutical product has arrived in a stable form. Ideally this should be non-destructive, simple to perform and if possible, be based on pharmacopeia recommendations and QbD considerations such as critical material quality attributes. (3) On board monitoring of the medicines environment during drone flight is required to record if or when conditions have deviated from the manufacturer's recommendations. Critical process parameters such as temperature, pressure, vibration frequency and $g$-force should be monitored. (4) Ensuring the security of the medicines within the drone supply chain is required, for example on board anti-tamper monitoring and recipient authentication is required. (5) Understanding the effect of drone failure during flight, considering both the consequences on the medicine and the environment is required. The work presented here has successfully addressed the first three of these tests, future work and collaboration with drone manufacturers will allow the development of the last two.

Supplementary Materials: The following are available online at http://www.mdpi.com/2504-446X/3/3/52/s1, S1. Preparation and Validation of Reference Standards: Table S1. Preparation of reference suspensions according to British Pharmacopoeia [23]; Figure S1. (a) Four reference suspensions prepared according to the BP. (b) Average absorbance of three batches of reference suspensions (formazin) plotted against opalescent values (NTU). UV calibration linear regression: Average absorbance at $350 \mathrm{~nm}=0.0058 \times$ opalescent values $\left(R^{2}=0.9999\right)$. Data points shown are the mean of $n=3$ measurements, with error bars indicating the standard deviations on these values. S2. Comparison of Insulin Solutions Stored in Pure Water and HCl: Table S2. Comparison of insulin solutions,10 $\mathrm{mg} / \mathrm{mL}$, stored for 24 hours at different temperatures, diluted to $0.2 \mathrm{mg} / \mathrm{mL}$ for analysis with either ultra-pure water or 0.01M HCl; S3. DLS Size Distribution Curve for Insulin: Figure S3. (a) Size distribution diameter in $\mathrm{nm}$ for diluted insulin samples $(0.2 \mathrm{mg} / \mathrm{mL}$, unfiltered before analysis) after $10 \mathrm{mg} / \mathrm{mL}$ insulin was being stored at respective temperatures for 24 hours. (b) Size distribution diameter in $\mathrm{nm}$ for $0.5 \mathrm{mg} / \mathrm{mL}$ insulin samples (unfiltered before analysis) after being agitated at respective agitation frequencies for 30 minutes; S4. Vibration Measurement Tests: Figure S4. The most frequently observed vibration frequency with respective acceleration magnitudes (g) during launching, initiation, in-flight and landing.

Author Contributions: Conceptualization, P.G.R.; data curation, M.S.Y.H.; formal analysis, M.S.Y.H. and P.G.R.; investigation, M.S.Y.H.; methodology, M.S.Y.H. and P.C.; project administration, P.G.R.; resources, P.G.R.; supervision, P.C. and P.G.R.; validation, P.C.; writing—original draft, M.S.Y.H.; writing—review and editing, P.C. and P.G.R.

Funding: This research received no external funding.

Acknowledgments: The authors would like to thank Janique Waghorn, Jig Patel, Lynda Cameron (Guy's and St Thomas'), Niusha Shekarian (Lloyds Pharmacy), Rita Shah (King's College Hospital), Gavin Goudie (Blue Bear Research Systems), Janick Mischler (Swiss Post), Przemyslaw Kornatowski (Dronistics) for their expert advice, as well as Philip Down (The Griffin Sportsground) for granting permission to fly drone at the sports ground. The authors would also like to thank Fitzroy Calliste for sourcing Actrapid (POM) and Steve Ingham for sourcing loads of different masses.

Conflicts of Interest: The authors declare no conflict of interest.

\section{References}

1. Department for Transport. Public Dialogue on Drone Use in the UK. 24 August 2017. Available online: https://assets.publishing.service.gov.uk/government/uploads/system/uploads/attachment_data/file/ 579550/drones-uk-public-dialogue.pdf (accessed on 5 October 2018).

2. Choi-Fitzpatrick, A.; Chavarria, D.; Cychosz, E.; Dingens, J.P.; Duffey, M.; Koebel, K.; Siriphanh, S.; Tulen, M.Y.; Watanabe, H.; Juskauskas, T.; et al. Up in the Air: A Global Estimate of Non-Violent Drone Use 2009-2015; Joan B. Kroc School of Peace Studies-University of San Diego: Degheri Alumni Center, CA, USA, 2016.

3. Karaca, Y.; Cicek, M.; Tatli, O.; Sahin, A.; Pasli, S.; Beser, M.F.; Turedi, S. The potential use of unmanned aircraft systems (drones) in mountain search and rescue operations. Am. J. Emerg. Med. 2018, 36, 583-588. [CrossRef] [PubMed] 
4. Balasingam, M. Drones in medicine-The rise of the machines. Int. J. Clin. Pr. 2017, 71, e12989. [CrossRef] [PubMed]

5. Nesta. Flying High: The Future of Drone Technology in UK Cities. July 2018. Available online: https: //www.nesta.org.uk/report/flying-high-challenge-future-of-drone-technology-in-uk-cities/ (accessed on 5 October 2018).

6. Bamburry, D. Drones: Designed for Product Delivery. Des. Manag. Rev. 2015, 26, 40-48.

7. Haidari, L.A.; Brown, S.T.; Ferguson, M.; Bancroft, E.; Spiker, M.; Wilcox, A.; Ambikapathi, R.; Sampath, V.; Connor, D.L.; Lee, B.Y. The economic and operational value of using drones to transport vaccines. Vaccine 2016, 34, 4062-4067. [CrossRef] [PubMed]

8. Thiels, C.A.; Aho, J.M.; Zietlow, S.P.; Jenkins, D.H. Use of Unmanned Aerial Vehicles for Medical Product Transport. Air Med. J. 2015, 34, 104-108. [CrossRef] [PubMed]

9. Fancher, J.C.; Zhao, M.H.; Chen, X.K.; Liu, Y.Z. Unmanned Drones for Medical Supply Delivery in China. Fac. Worcest. Polytech. Inst. 2017, 1, 1-87.

10. Van De Voorde, P.; Gautama, S.; Momont, A.; Ionescu, C.M.; De Paepe, P.; Fraeyman, N. The drone ambulance [A-UAS]: Golden bullet or just a blank? Resuscitation 2017, 116, 46-48. [CrossRef] [PubMed]

11. Güner, S.; Rathnayake, D.; Baba Ahmadi, N. Using Unmanned Aerial Vehicles—Drones as a Logistic Method in Pharmaceutical Industry in Germany. Aviation 2017, 1, 1-11.

12. Scott, J.E.; Scott, C.H. Models for Drone Delivery of Medications and Other Healthcare Items. Int. J. Healthc. Inf. Syst. Inform. (IJHISI) 2018, 13, 20-34. [CrossRef]

13. Goodchild, A.; Toy, J. Delivery by drone: An evaluation of unmanned aerial vehicle technology in reducing CO2 emissions in the delivery service industry. Transp. Res. Part D 2018, 61, 58-67. [CrossRef]

14. Amukele, T.; Ness, P.M.; Tobian, A.A.R.; Boyd, J.; Street, J. Drone transportation of blood products. Transfusion 2017, 57, 582-588. [CrossRef] [PubMed]

15. Amukele, T.K.; Sokoll, L.J.; Pepper, D.; Howard, D.P.; Street, J. Can Unmanned Aerial Systems (Drones) Be Used for the Routine Transport of Chemistry, Hematology, and Coagulation Laboratory Specimens? PLoS ONE 2015, 10, e0134020. [CrossRef] [PubMed]

16. Amukele, T.K.; Hernandez, J.; Snozek, C.L.; Wyatt, R.G.; Douglas, M.; Amini, R.; Street, J. Drone Transport of Chemistry and Hematology Samples Over Long Distances. Am. J. Clin. Pathol. 2017, 148, 427-435. [CrossRef] [PubMed]

17. Katariya, M.; Chung, D.C.K.; Minife, T.; Gupta, H.; Zahidi, A.A.A.; Liew, O.W.; Ng, T.W. Drone inflight mixing of biochemical samples. Anal. Biochem. 2018, 545, 1-3. [CrossRef] [PubMed]

18. Civil Aviation Authority. The Drone Code. July 2018. Available online: https://dronesafe.uk/wp-content/ uploads/2018/06/Dronecode_2018-07-30.pdf (accessed on 5 October 2018).

19. Civil Aviation Authority. Drone Safety Risk: An Assessment. January 2018. Available online: https: //publicapps.caa.co.uk/docs/33/CAP1627_Jan2018.pdf (accessed on 5 October 2018).

20. Yoo, W.; Yu, E.; Jung, J. Drone delivery: Factors affecting the public's attitude and intention to adopt. Telemat. Inform. 2018, 35, 1687-1700. [CrossRef]

21. Alemu, S.; Dessie, A.; Seid, E.; Bard, E.; Lee, P.T.; Trimble, E.R.; Phillips, D.I.; Parry, E.H. Insulin-requiring diabetes in rural Ethiopia: Should we reopen the case for malnutrition-related diabetes? Diabetologia 2009, 52, 1842-1845. [CrossRef] [PubMed]

22. Akbarian, M.; Ghasemi, Y.; Uversky, V.N.; Yousefi, R. Chemical modifications of insulin: Finding a compromise between stability and pharmaceutical performance. Int. J. Pharm. 2018, 547, 450-468. [CrossRef]

23. Schweitzer, M.; Pohl, M.; Hanna-Brown, M.; Nethercote, P.; Borman, P.; Hansen, G.; Kevin Smith, K.; Jaqueline Larew, J. Implications and Opportunities of Applying QbD Principles to Analytical Measurements. Pharm. Technol. 2010, 34, 1-4.

24. British Pharmacopoeia Commission. Appendix IV: A. Clarity of Solution; British Pharmacopoeia: London, UK, 2018.

25. Wang, W.; Wang, Y.J.; Wang, D. Dual effects of Tween 80 on protein stability. Int. J. Pharm. 2008, 347, 31-38. [CrossRef]

26. Mahler, H.-C.; Muller, R.; Frie $\beta$, W.; Delille, A.; Matheus, S. Induction and analysis of aggregates in a liquid IgG1-antibody formulation. Eur. J. Pharm. Biopharm. 2005, 59, 407-417. [CrossRef]

27. Teplow, D.B. Preparation of Amyloid $\beta$-Protein for Structural and Functional Studies. Methods Enzymol. 2006, 413, 20-33. [PubMed] 
28. DJI. Mavic Air Specs. 2018. Available online: https://www.dji.com/uk/mavic-air/info (accessed on 8 October 2018).

29. Past Weather in London, England, United Kingdom. 2018. Available online: https://www.timeanddate.com/ weather/uk/london/historic?month=12\&year=2018 (accessed on 20 December 2018).

30. Mahler, H.-C.; Friess, W.; Grauschopf, U.; Kiese, S. Protein aggregation: Pathways, induction factors and analysis. J. Pharm. Sci. 2009, 98, 2909-2934. [CrossRef] [PubMed]

31. British Pharmacopoeia Commission. Formulated Preparations: Specific Monographs_Insulin Injection; British Pharmacopoeia: London, UK, 2018.

32. Pease, L.F.; Sorci, M.; Guha, S.; Tsai, D.-H.; Zachariah, M.R.; Tarlov, M.J.; Belfort, G. Probing the Nucleus Model for Oligomer Formation during Insulin Amyloid Fibrillogenesis. Biophys. J. 2010, 99, 3979-3985. [CrossRef] [PubMed]

33. Posada, D.; Tessier, P.M.; Hirsa, A.H. Removal Versus Fragmentation of Amyloid-forming Precursors via Membrane Filtration. Biotechnol. Bioeng. 2012, 109, 840-845. [CrossRef] [PubMed]

34. Grainger, R.; Ko, S.; Koslov, E.; Prokop, A.; Tanner, R.; Loha, V. Effect of Shear on Human Insulin in Zinc Suspension. Appl. Biochem. Biotechnol. 2000, 84, 761-768. [CrossRef]

35. Harvey, D. Spectroscopy Based on Scattering. 3 May 2016. Available online: https: //chem.libretexts.org/Bookshelves/Analytical_Chemistry/Book\%3A_Analytical_Chemistry_2.0_(Harvey) /10_Spectroscopic_Methods/10.8\%3A_Spectroscopy_Based_on_Scattering (accessed on 9 January 2019).

36. Analite Australia. Turbidity Calibration Standards. 28 January 2018. Available online: https:/analite.com. au/turbidity-calibration-standards/ (accessed on 9 January 2019).

37. Thorne, R.S.W. Application of Formazin Standards to Nephelometric Estimation of Beer Turbidity. J. Inst. Brew. 1961, 67, 191-199. [CrossRef]

38. Malvern Instruments Ltd. Zetasizer Nano Series User Manual. February 2014. Available online: http://www.biophysics.bioc.cam.ac.uk/files/Zetasizer_Nano_user_manual_Man0317-1.1.pdf (accessed on 8 November 2018).

39. Zhou, C.; Qi, W.; Lewis, E.N.; Carpenter, J.F. Characterization of Sizes of Aggregates of Insulin Analogs and the Conformations of the Constituent Protein Molecules: A Concomitant Dynamic Light Scattering and Raman Spectroscopy Study. J. Pharm. Sci. 2016, 105, 551-558. [CrossRef]

40. Eberlein, G.A.; Stratton, P.R.; Wang, Y.J. Stability of rhbFGF as determined by UV Spectroscopic Measurements of Turbidity. PDA J. Pharm. Sci. Technol. 1994, 48, 224-230.

41. Wang, W.; Roberts, C.J. Protein aggregation-Mechanisms, detection, and control. Int. J. Pharm. 2018, 550, 251-268. [CrossRef]

42. Kerr, D.; Wizemann, E.; Senstius, J.; Zacho, M.; Ampudia-Blasco, F.J. Stability and Performance of Rapid-Acting Insulin Analogs Used for Continuous Subcutaneous Insulin Infusion: A Systematic Review. J. Diabates Sci. Technol. 2013, 7, 1595-1606. [CrossRef]

43. Sadhale, Y.; Shah, J.C. Stabilization of insulin against agitation-induced aggregation by the GMO cubic phase gel. Int. J. Pharm. 1999, 191, 51-64. [CrossRef]

44. Sykes, C. Time- and Temperature-Controlled Transport: Supply Chain Challenges and Solutions. P T: A peer-reviewed. J. Formul. Manag. 2018, 43, 154-170.

45. Miller, M.A.; Rodrigues, M.A.; Glass, M.A.; Singh, S.K.; Johnston, K.P.; Maynard, J.A. Frozen-State Storage Stability of a Monoclonal Antibody: Aggregation is Impacted by Freezing Rate and Solute Distribution. J. Pharm. Sci. 2013, 102, 1194-1208. [CrossRef] [PubMed]

46. Mischler, J. personal Skype interview (Swiss Post). 12 December 2018.

47. Accuweather. Gondar Ethiopia Weather. 2018. Available online: https://www.accuweather.com/en/et/ gondar/127184/month/127184?monyr=1/01/2018 (accessed on 10 November 2018).

48. Electronic Medicines Compendium (eMC). Actrapid 100 International Units/ML, Solution for Injection in a Vial. Available online: https://www.medicines.org.uk/emc/product/3849/smpc (accessed on 26 December 2018).

49. Axelsson, M.A.D. Drones in arctic environments. PhD Thesis, Königliche Technische Hochschule, Stockholm, Sweden, 2017.

50. Malik, R.; Roy, I. Probing the mechanism of insulin aggregation during agitation. Int. J. Pharm. 2011, 413, 73-80. [CrossRef] [PubMed] 
51. Zhang, C.; Li, J.; Zhang, L.; Zhou, Y.; Hou, W.; Quan, H.; Li, X.; Chen, Y.; Yu, H. Effects of mechanical vibration on proliferation and osteogenic differentiation of human periodontal ligament stem cells. Arch. Oral Boil. 2012, 57, 1395-1407. [CrossRef] [PubMed]

52. Kornatowski, P. personal Skype interview (Dronistics). 19 November 2018.

53. Goudie, G. Skype personal interview (Blue Bear Systems Research). 5 December 2018.

54. COPTRZ. Understanding Drone Payloads. 7 June 2016. Available online: https://www.coptrz.com/ understanding-drone-payloads/ (accessed on 2 January 2019).

55. Shekarian, N.; Cameron, L.; Patel, J.; Shah, R.; Waghorn, J. Email or personal interview. 15 October; 2018.

(C) 2019 by the authors. Licensee MDPI, Basel, Switzerland. This article is an open access article distributed under the terms and conditions of the Creative Commons Attribution (CC BY) license (http://creativecommons.org/licenses/by/4.0/). 